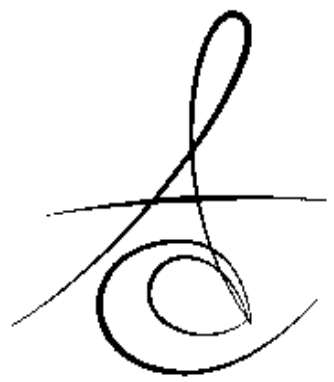

\title{
MAKSİLLER SİNÜS AUGMENTASYONLARINDA TROMBOSİTTEN ZENGİN PLAZMANIN KULLANIMI: BİR DERLEME ÇALIŞMASI
}

\author{
USE OF PLATELET RICH PLASMA DURING SINUS FLOOR \\ AUGMENTATION: A REVIEW STUDY
}

\author{
Dr. Songül CÖMERT KILIÇ*
}

Makale Kodu/Article code: 2767

Makale Gönderilme tarihi; 04.04.2016

Kabul Tarihi: 22.04.2016

öz

Maksillanın posterior bölgesinde yetersiz alveolar kemik hacmi yıllardır implat-destekli rehabilitasyon için kesin bir kontrendikasyon oluşturmaktadır. Şiddetli atrofik maksiller posterior bölgeye sahip hastalarda, dental implantların güvenle yerleştirilmelerini sağlayacak yeterli kemik hacmi oluşturmak amacıyla sinus tabanının yükseltilmesi ve Schneiderian membrane ile sinus tabanı arasına kemik greft materyalinin eklenmesi yöntemi yani maksiller sinüs augmentasyonu kullanılmaktadır. Çok sayıda büyüme faktörü içeren Trombositten zengin plazmanın (Platelet Rich PlasmaPRP), sinus augmentasyonunda kullanılan kemik greft materyaline eklenmesinin daha iyi kemik rejenerasyonu ve doku iyileşmesi sağladığı iddia edilmiştir. Bu çalışmanın amacı PRP hakkında bilgi vermek ve Sinus augmentasyonunda PRP kullanımının etkinliği ile ilgili literatür incelemesi yapmaktır.

Anahtar Kelimeler: Sinüs Augmentasyonu, Trombositten Zengin Plazma

\section{ABSTRACT}

Inadequate alveolar bone volume in the posterior maxilla has been considered for many years as an absolute contraindication for implant-supported rehabilitation. Elevation of the sinus floor and then adding bone substitute material between Schneiderian membrane and floor of the maxillary sinus have been used to provide adequate bone volume and bone room for safe implant placement in patients with extremely atrophic posterior maxilla. It has been claimed that PRP (platelet rich plasma), which contains many growth factors, could produce better bone regeneration and wound healing when added to bone graft material used to sinus floor augmentation. This study aimed to give information about PRP, and to presents a review of the literature about effectiveness of PRP during sinus floor augmentation.

Key Words: Sinus Augmentation, Platelet Rich Plasma
Maksiller sinüs augmentasyonu, posterior maksillada implant uygulanacak bölgede yeterli kemik yüksekliğini sağlamak ve yerleştirilen implantın başarısını artırmak amacıyla yaygın bir yöntem olarak kullanılmaktadır. Bu bölgede kemik dokusunun rejenerasyonu ve rekonstrüksiyonunu sağlamak için çeşitli kemik greftleri, bariyer membranlar ve bazı proteinlerin kullanımı önerilmektedir.

Greft materyalinin başarılı bir şekilde vaskülerizasyonu ve stabilizasyonu sağlandığında, yeni kemik rejenerasyonu vuku bulacaktır. Bir otojen kemik greftinde yeni kemik rejenerasyonu 3 farklı karakteristiğin varlığına bağlı olarak gerçekleşmektedir: Osteogenezis, osteoindiksüyon, osteokondüksiyon. ${ }^{1}$ Bu 3 farklı karakteristik farklı greft materyallari kullanıldığında farklılıklar göstermektedir.

Osteogenezis greftin uygulandığı bölgedeki lokal kemikte bulunan yada greft kemiğinden kaynaklanan osteopregenitor hücrelerin yeni kemik oluşturması olarak tarif edilebilir. Osteogenetik özelliğe sahip en iyi greft materyalinin otojen kemik greftleri oldukları kabul edilmektedir. ${ }^{2}$

Osteoindiksiyon; differansiye olmamış pluripotent kök hücrelerin kemik yapıcı hücrelere farklılaş-

*Erzurum Ağız ve Diş Sağlığı Merkezi, Ağız Diş ve Çene Cerrahisi Kliniği, 
masının uyarılma süreci içermektedir. ${ }^{2}$ Pluripotent kök hücreler kemikte bulunmakta olup, kemik iyileşmesi için temel bir gereklilik oluşturmaktadır. Bu hücrelerin öncü osteoblatlar ve takiben de kemik yapıcı osteoblastlara dönüşmesi için gerçek bir stimulus gereklidir. Kemik morfogenetik proteinler en çok bilinen osteoindüktif ajanlardır. Kemik morfogenetik proteinleri (BMPs), transforming büyüme faktörü $\beta$ (TGF- $\beta$ ) üst ailesine ait glikoproteinlerdir. ${ }^{2}$

Osteoindüktif kapasiteye sahip çok sayıda BMPs bulunmaktadır ve bunlardan BMP-2, BMP-6, BMP-7 ve BMP-9 en çok etkili olanlarındandır. Bu proteinlerin varlığında kemik formasyonunun endokondral ossifikasyon yoluyla oluştuğu kabul edilmektedir. ${ }^{3}$

Osteokondiksiyon; greft materyalinin bir özelliği olup, hücrelerin migrasyonuna izin vermesi ve kan damarlarının greft materyalinin içine ve yüzeyine büyümesi gibi özelliklerdir. Greft materyali biyo-inert bir özelliktedir ve greft materyali vasküler büyüme ve kemik formasyonu için sadece yapısal bir platform (scaffold) oluşturmaktadır. Sadece osteokonduktif özelliğe sahip olan bir greft kemik formasyonunu başlatamaz ve dolayısıyla kemik formasyonu oluşturamaz. ${ }^{2,4}$

Otojen greft materyalleri veya diğer greft materyallerinin kullanımı sonrasında gelişebilecek bir takım dezavantajları azaltmak veya ortadan kaldırmak amacıyla uygulanan greft materyaline bazı büyüme faktörlerinin ilave edilerek kullanılması önerilmektedir. Kemik dokusunun rejenerasyon ve rekonstrüksiyonunda, kullanılan bu materyallere ek olarak, kemik oluşumunun indüklenmesinde büyüme faktörlerinin de önemli etki gösterebileceği bilinmektedir. Büyüme faktörlerinin hücre proliferasyonunda, farklılaşmasında, kemotaksisinde ve ekstraselüler matriks sentezinde rol alabilecekleri düşünülmektedir. Kemik greftlerine büyüme faktörlerinin eklenmesinin ayrıca kemik rejenerasyonunu artırabileceği ve daha hızlı kemik oluşumu sağlayabileceği iddia edilmektedir., ${ }^{5,6}$

Trombositten Zengin Plazma (Platelet Rich Plasma-PRP)

Kan plazmasında bulunan plateletlerin içerisinde çok sayıda osteoindüktif büyüme faktörleri bulunmaktadır. Bunlardan bazıları şunlardır: Platelet Kaynaklı Büyüme Faktörü (Platelet Derived Growth Factor = PDGF), Transforme Edici Büyüme FaktörüBeta (Transforming Growth Factor- $\beta=$ TGF- $\beta$ ), Trombosit Faktör 4 (Platelet Factor $4=$ PF4) ve İnsülin Benzeri Büyüme Faktörü (Insulin Like Growth Factor =
IGFs). Plateletten Zengin Plazma (Platelet Rich Plasma-PRP) yüksek oranda bu büyüme faktörlerini ve plateletleri içeren otojen bir plazmadır. ${ }^{6}$ PRP son yıllarda özellikle kemik rejenerasyonunu içeren, sert ve yumuşak dokuların rejenerasyonu amacıyla genel olarak Tıp ve Diş Hekimliği ile Spor Hekimliği ve Kozmetik Tıp gibi birçok alanda ve spesifik olarak da Baş-Boyun Cerrahisi, KBB, Oral ve Maksillofasiyal Cerrahi, Kardiyovasküler Cerrahi, Periodontoloji ve Ortopedi gibi pek çok branşta kullanım alanı bulmuş ve çok sayıda sağlık merkezinde sıklıkla başvurulan tedavi yöntemleri arasında yer almıştır ve almaya da devam etmektedir. ${ }^{3,7}$

PRP denekten alınan otolog kanın çeşitli yöntemler kullanılarak santrifüj edilmesiyle elde edilen, içerisinde normal plazmadan 3-5 kat kadar fazla trombosit bulunduran kan plazmasıdır. ${ }^{2}$ PRP içerisinde bulunan trombositler ve trombositlerden salgilanan büyüme faktörleri yara iyileşmesi sürecindeki olayların regülasyonu için gerekli yapı taşlarını oluşturmaktadır. Kemik greftlerine PRP'nin ilave edilerek kullanılması fikri ilk kez Robert Marx tarafından ortaya atılmış ve günümüzde de yaygın kullanım alanı bulmuştur.8,9

Literatürde en az 15 büyüme faktörünün trombositlerde mevcut olduğu ortaya konulmuştur: ${ }^{10-12}$ Transforming büyüme faktörü- $\beta$, platelet faktör 4 , interlökin $1-\beta$, platelet kaynaklı angiogenezis faktör, vasküler endotelyal büyüme faktörü, epidermal büyüme faktörü, platelet-kaynaklı endotelyal büyüme faktörü, epitelyal hücre büyüme faktörü, insulinbenzeri büyüme faktörü, osteokalsin, osteonektin, fibrinojen, vitronektin, fibronektin ve trombospontin-1

PRP'nin doku iyileşmesinde gerekli olan enflamasyon, proliferasyon ve remodeling gibi hücresel aktiviteleri uyarıcı ve düzenleyici bir role sahip olduğu iddia edilmiştire. ${ }^{13-16}$

PRP'nin içerdiği büyüme faktörlerinin aktivasyonuyla yara iyileşmesi ve osteogenezi hızlandırdığı, osteokondüksiyonu arttırdığı, otojen olarak elde edildiği için çapraz kontaminasyon riski taşımamadığı ve hemostaz etkisi olması yönüyle postoperatif kanama riskini azalttığı yapılan çalışmalarda belirtilmiştir. ${ }^{12,15-18}$

PRP Diş Hekimliğinde çeşitli klinik uygulama alanları bulmuştur. Sinüs augmentasyonu ve diğer greftlemeler, alveoler augmentasyonlar, diş ya da dişlerin çekimi veya küçük kistlerin çıkarılmasıyla oluşabilecek kemik defektlerinin tamiri, alveoler koruma teknikleri, periodontal defektlerin tamiri, yarık dudak

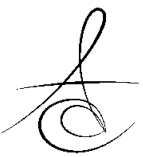


ve damak defektlerinin kapatılması, oro-antral fistüllerin kapatılması, kranio-fasiyal rekonstrüksiyonlar gibi kemik rejenerasyonu uygulamalarında ve periosteal ve bağlantı dokusu flepleri, serbest bağlantı ataşmanı ve diş eti greftlerinde, kök kaplanması prosedürleri, yumuşak doku iyileşmesi ve doku maturasyonu gibi alanlarda kullanılmaktadır. ${ }^{19}$

\section{PRP İçindeki Başlıca Büyüme Faktörleri}

PRP çok sayıda büyüme faktörü içermektedir. Bunlardan en önemlileri aşağıda tanıtılmıştır.

1. PDGF (Platelet Derived Growth Factor =Trombosit Kaynaklı Büyüme Faktörü):

PDGF plateletlerin a granüllerinde depolanır ve pıhtılaşma sırasında salınır. PDGF hemen hemen tüm yara iyileşmelerinde rol alan bir büyüme faktörüdür. PDGF plateleter içindeki birincil büyüme faktörü olmasına rağmen, bu büyüme faktörü monositler, makrofajlar, düz kas hücreleri ve diğer endotelyal hücreler tarafından da sentezlenip salınabilir. Kan pıhtısında plateletlerin bulunması sebebiyle, yara iyileşmesinde de birincil büyüme faktörü olarak PDGF salınmakta olup, PDGF revaskülarizasyon, kollajen senetezi ve kemik rejenerasyonununu sağlayan bir büyüme faktörüdür.

PDGF'nin yara iyileşmesi üzerinde çok fazla olumlu etkisi bulunmaktadır. Bu etkileri:

1. Mitogenez (iyileşme hücrelerinin sayısında artmaya sebep olma)

2. Anjiogenez (yeni kapiller oluşturma)

PDGF hedef hücrelerdeki hücre membran reseptörlerine bağlandığında PDGF'nin etkileri görülmeye başlar. Bu bağlanma ile aktive olan yüksek enerjili fosfat bağı ve sitoplazmik sinyal proteini mitoz, anjiogenez, makrofaj aktivasyonu gibi spesifik olaylar için gerekli genetik uyarıları yapar. Böylece iyileşme hücrelerinin sayısında bir artış olur, mitozis, anjinogenezis, kapillerin organizasyon, makrofaj aktivasyonu ile diğer büyüme faktörleri ve hücrelerin üst düzenlenmesi gibi spesifik aktiviteler oluşur. 9,20,21 $^{2}$

2. TGF- $\beta$ (Transforming Growth Factor= Transforme Edici Büyüme Faktörü-Beta)

TGF- $\beta 1$, TGF- $\beta 2$, TGF- $\beta 3$ şeklinde 3 farklı gen ürünü olarak ortaya çıkar. TGF- $\beta 1$ kemikte ve plateletlerde yüksek konsantrasyonda bulunur. Trombositlerce salgılanır. Ayrıca makrofajlar, osteoblastlar ve diğer bazı hücreler tarafından da salgılanır ve bu hücrelerde bulunurlar.

TGF- $\beta$, otokrin ve parakrin mekanizmaların her ikisinde de görev alan ana düzenleyici bir moleküldür.
Plateletler veya makrofajlar tarafından salındığında, TGF- $\beta$ etkilerini; fibroblastlar, kemik iliği kök hücreleri, endotelyal hücreler ve preosteoblastları içeren komşu hücreler üzerinde gösterir. TGF- $\beta$ anjiogenezisi, fibronektin, glikozaminoglikanlar ve konnektif dokudaki kollajen üretimini stimüle eder. TGF- $\beta$ 'nın en önemli görevlerinden biri osteoblast öncü hücrelerinin kemotaksisi ve mitogenezisini sağlamasıdır.TGF- $\beta$ bir büyüme faktörü mekanizması olarak, sadece kemik rejenerasyonunu uyarmaz, aynı zamanda uzun dönem iyileşme ve kemik rejenerasyonunun devamını sağlayarak, kemik greftinin olgunlaşmasına kadar etki gösterir. ${ }^{9,19}$

3. PDEGF ( Platelet Derived Epidermal Growth Factor=Trombosit Kaynaklı Epidermal Büyüme Faktörü)

PDEGF ilk tanımlanan büyüme faktörüdür. Epidermal rejenerasyonu ve anjiogenezisi uyarır. Dermal fibroblast ve keratinosit proliferasyonunu uyararak yara iyileşmesini düzenler ve artırır. Diğer büyüme faktörlerinin etkilerini ve üretimini arttırır. ${ }^{9,19}$

4. PDAF (Platelet Derived Angiogenezis Factor=Trombosit Kaynaklı Anjiojenezis Faktörü )

PDAF in-vivo olarak vaskülarizasyonu indükleme kapasitesine sahip olan bir faktördür. Direkt ve indirekt yollarla vasküler endotelyal hücreleri stimule eder ve yeni kan damarlarının devaskülarize doku içine invazyonunda rol alır.9,19

5. IGF-1 ( Insulin Like Growth Factor 1= İnsülin Benzeri Büyüme Faktörü 1)

Kemik formasyonunda osteoblastlar tarafından salgılandığı ve bu yolla osteoblastları sayısını ve dolayısıyla yeni kemik depozisyonunu artırdığı düşünülmektedir. Kıkırdak büyümesi, kemik matriksi formasyonu ve osteoblastlar ve osteoklastların replikasyonunu stimüle eder.

IGF-1 hücreleri direkt stimüle edebilir. Osteoblastik hücrelerde alkalen fosfatazı aktive eder ve arttırır. IGF-1, PDGF ile kombine olarak çalıştıklarında yara iyileşmesinin kalitesini ve hızını arttırabilir.9,19

\section{PF-4 (Platelet Factor $4=$ Trombosit}

\section{Faktör 4)}

PF-4 nötrofiller için bir kemoatraktandır ve a granüllerinden salınarak nötrofillerin yara bölgesine ilk ulaşmasından kısmi olarak sorumlu olabilir. Ayrıca fibroblastlar için de bir kemoatraktan olarak hareket eder ve kuvvetli bir antiheparin ajanıdır. ${ }^{9,19}$ 


\section{FGF (Fibroblast Growth Factor =} Fibroblast Büyüme Faktörü)

FGF anjiiyogenezis, endotelyal hücre prolirerasyonu, kollojen sentezi, yara kontraksiyonu, matrix sentezi ve epitelizasyonunu uyarıcı etki göstermektedir. ${ }^{19}$

8. VEGF (Vascular Endothelial Growth Factor=Vasküler Endotelyal Büyüme Faktörü)

Anjiogenezi stimule eder. Ayrıca damarsal hiper-permeabilite sağlayarak endotelyal hücrelerin kemotaksisi ve proliferasyonu üzerinde etkili bir faktördür. VEGF'nin dört izoformu bulunmaktadır. ${ }^{22}$

9. EGF (Epithelial Growth Factor=Epitelyal Büyüme Faktörü)

Epitelyal büyüme faktörü, endotelyal hücreler, fibroblastlar, renal hücreler, mezenşimal hücrelerden kaynaklanan glial hücreler üzerinde mitojenik, proapoptik ve migrasyonu ile farklılaşma aktivitesini destekleyici potansiyele sahiptirler. Epitelizasyonu desteklerler. ${ }^{23}$

\section{PRP'nin Elde Edilmesi}

Temel olarak bakıldığında, trombositlerin dolayısıyla içerdikleri büyüme faktörlerinin santrifüj edilerek venöz kandan ayrıştırıması ve az bir miktar plazma içerisinde süspansiyon haline getirilmesi ile PRP elde edilir. Dohan Ehrenfest ve ark. ${ }^{24}$ yaptıkları bir derlemede fibrin ve lökosit içeriğine göre trombosit konsantrasyonlarını sınıflamış ve PRP elde etme yöntemlerini lökosit içeriğine göre otomatik sistemler ile elde edilen ve manuel olarak elde edilen yöntemleri belirterek lökositten zengin PRP (L-PRP) ve lökositten fakir PRP (P-PRP) olarak ikiye ayırmış ve bu çalışmalarında ayrıntıı olarak anlatmışlardır.

PRP' nin manuel olarak eldesinde esas olarak tek ve çift spinli santrifüj yöntemleri kullanılmaktadır. Tek spin santrifüj tekniği olan Anitua'nın PRGF'si ilk olarak 1999 da tanımlanmışır ${ }^{25}$ Bu metodda hastadan alınan kan antikoagülan içeren tüplere konularak oda sıcaklığında tek aşamalı santrifüj işlemine tabi tutulmaktadır. Santifüj sonrası tüpte altta kırmızı kan pıhtısı (RBCs) tabakası, ortada lökosit ve trombosit içeren "buffy coat" tabakası ve en üstte aselüler plazma veya trombositten fakir plazma (PPP) olmak üzere 3 tabaka oluşmaktadır. Bu teknikte PPP tabakası uzaklaştııılarak, buffy coat tabakası pipetle alınır.

Çift spinli santrifüj tekniğinde hastadan alınan tam kan antikoagülanlı tüplere alındıktan sonra santrifüj edilir. Santifüj sonrası tüpte RBCs tabakası, buffy coat ve PPP bulunduğu 3 tabaka oluşmaktadır.
PPP ve buffy coat tabakası dikkatlice pipetle boş tüpe aktarlıp, ikinci daha yüksek bir devirde santrifüj yapilır ve santrifüj sonrası tüpte üst kısımda PPP, altta PRP'nin oluştuğu iki tabaka oluşur. Üstteki PPP kısım dikkatlice uzaklaştırılıp, PRP uygun koşullarda alııır. Manuel yöntemler esas olarak bu şekilde tanımlansa da, literatürde zaman içinde çeşitli modifikasyonlar geliştirildiği gözlemlenmiştir.

PRP elde edildikten sonra antikoagülan etkinin ortadan kalkması için $\mathrm{CaCl}_{2}$ ilaveleri gerekli olup, trombositlerin aktive edilip granül içeriklerini boşaltmalarını sağlamak için ise PRP nin trombin ya da hastanın kendi kanı ile karışııııması gereklidir.

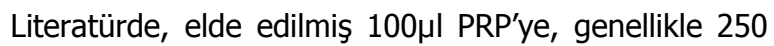
veya 300 IU trombin ve 100 veya $500 \mu \mathrm{l} \% 10^{\prime}$ luk $\mathrm{CaCl}_{2}$ ilavesi yapıldığı gözlemlenmiştir.

PRP kullanımımın avantajları

PRP kullanımımın çok sayıda avantajı bulunmaktadır. Bunlar: ${ }^{12,15-18}$

1. Kolay ve kısa sürede elde edilebilmektedir.

2. PRP'nin içerdiği büyüme faktörlerinin aktivasyonuyla yara iyileşmesi hızlanmaktadır.

3. Büyüme faktörlerinin içerdiğinden dolayı osteogenezi hızlandırmaktadır.

4. Osteokondüksiyonu arttırarak greftin kemikle olan birleşmesini kolaylaştırmaktadır.

5. Otojen olarak elde edildiği için çapraz kontaminasyon riski taşımamaktadır ve bu sebeple güvenle uygulanabilir.

6. Yüksek oranda lökosit içerdiğinden kronik yaralarda topikal olarak kullanılabilmektedir.

7. PRP'nin hemostaz etkisi olması yönüyle postoperatif kanama riski azalmaktadır

8. Greft materyaliyle birlikte uygulaması ve manuplasyonu kolaydır.

\section{PRP kullanımımın dezavantajları}

PRP'nin hazırlanması için santrifüj cihazı gerektirmesi ve bu durumun belirli bir maliyet gerektirmesi dezavantajları arasında sayılabilir. Ayrıca PRP'nin hazırlanması için belli bir süre gerektirmesi de bazen bir dezavantaj olarak karşımıza çıkmaktadır. ${ }^{12,15}$

\section{PRP Uygulamasının Kontrendikasyonları: ${ }^{19}$}

1. Hemoglobin seviyesinin düşük olduğu sebebi bilinmeyen anemi $(\mathrm{Hg}<12.5 \mathrm{gr} \%)$

2. Trombositopeni

3. Tanısı konulmuş ve tedavi edilmiş ancak $\mathrm{Hg}<10$ gr olduğu durumlarda

4. Metastatik hastalığı olanlarda

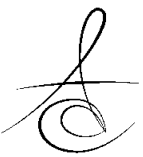


5. İyileşme bölgesinde tümör bulunması

6. Platelet disfonksiyon anemnezi olanlar

7. Sistemik antibiyotik kullanımı gerektiren aktif yara enfeksiyonu ve sepsisi olanlar

8. Diğer hastalıkları sebebiyle düşük prognozu olanlar

9. Dini inanışı kan kullanımını yasaklayan hastalar.

\section{Sinüs Augmentasyonu Teknikleri}

Sinüs boşluğuna ulaşmak amacıyla bir kemik penceresi açılmasını ve bu pencereden sinüs membranının yükseltilmesi sağlanarak, greft materyali için bir boşluğun oluşturulması işlemi sinüs augmentasyonu olarak bilinmektedir. Sinüs boşluğu yoluyla alveoler krestin yükseltilmesi ve rekontsrüksiyonu fikri ve tekniği ilk kez yaklaşık 40-50 yıl önce ve Dr. Boyne $^{26}$ ve Dr. Tatum ${ }^{27}$ tarafından ortaya atılmıştır. Sinüse pencere açma fikri daha sonra kabul görmüş ve dünyada yaygın olarak kullanılmaya başlamıştır.

Sinus augmentasyonu için çok sayıda yöntem tanitılmış olmasına rağmen, bugün için en çok kullanılan 2 yöntem vardır: 1-Lateral pencere tekniği veya açık sinüs lift tekniği veya direkt sinüs lift tekniği, ${ }^{27} 2$ - sinüs intrizyon osteotomi tekniği veya kapalı lift tekniği veya indirekt sinüs lift tekniği. ${ }^{28} \mathrm{Bu}$ metotların her ikisinin de maksiller posterior bölgedeki vertikal yöndeki augmentasyonda en stabil teknikler olduğu kabul edilmektedir. Bu iki teknikte de otojen greftler, allogreft, xenogreft, alloplastik materyaller rahatıkla greft materyali olarak kullanılabilmektedir. Bu yöntemlerden farklı olarak minimal invaziv yöntem, ${ }^{29}$ balon tekniği, ${ }^{30}$ su basıncı kullanılarak membran elevasyonu ${ }^{31}$ ile negatif basınç tekniğ ${ }^{32}$ ile sinüs tabanı yükseltmesi gibi yöntemler de literatürde yerini bulmuştur.

\section{PRP'nin sinüs augmentasyonunda etkinliği}

Maksiller sinüs augmentasyonunda greft materyaline PRP eklenmesi veya tek başına PRP kullanımıyla ilgili sınırlı sayıda klinik ve deneysel çalışmalar yapılmıştır.

Major ve ark. ${ }^{33} 5 \mathrm{~mm}$ den daha az krestal yüksekliğe sahip olan ve sinüs augmentasyonu endikasyonu olan 105 hastada otojen kemik grefti ve PRP'yi implant uygulamasıyla eş zamanlı olarak uygulamışlardır. Bu klinisyenler uyguladıkları bütün implantların klinik olarak osteointegre olduklarını gözlemlemişlerdir. Ayrıca PRP eklenmesinin kemik maturasyon süresini azalttığını, greftin uygulama kolaylığı sağladığını ve yumuşak doku iyileşmesini artırdığını bildirmişlerdir.
Bettega ve ark. ${ }^{34}$ sinüs augmentasyonunda otojen kemik greftine PRP ekledikleri 18 hastada, augmentasyon sonrasında kemik oluşumunu değerlendirmişler ve PRP eklenmesinin kemik rekonstrüksiyonuna yardımcı olabileceğini bildirmişlerdir.

Riaz ve ark. ${ }^{35}$ PRP + hidroksiapatit kristallari (6 hasta) ile sadece otojen greftin (4 hasta) sinüs augmentasyonunda etkinliğini toplam 10 hastada 3 yıl süreyle değerlendirmişlerdir. Tüm hastalarda augmentasyon öncesi $5 \mathrm{~mm}$ den daha az olan kemik yüksekliğinin işlemler sonrasında $15 \mathrm{~mm}$ olduğunu, ancak hidroksiapatit kristallari ile PRP kombinasyonunun, sadece otojen greft uygulanan gruptaki hastalara göre kemik yüksekliğinde daha etkili olduğunu bildirmişlerdir.

Thor ve ark. ${ }^{36}$ maksiller sinüs augmentasyonunda greft uygulamasinda PRP eklenmesinin erken ve geç dönem kemik iyileşmesine olan etkilerini histomorfometrik olarak incelemişlerdir. Bu araştırıcılar kontrol bireylerine nispeten PRP uygulanan bireylerde uygulamayı takip eden 3 aylık sürede, daha fazla yeni kemik oluşumunun sağlandığını, fakat bu olumlu etkinin 6 ay sonra gözlemlenmediğini rapor etmişlerdir.

Schlegel ve ark. $^{37}$ köpeklerde yapılan sinüs augmentasyonunda otojen greft ve PRP kombinasyonunu, hidroksiapatit ve PRP kombinasyonuyla karşılaşırmışlar ve bu iki farklı kombinasyonun benzer oranda kemik iyileşmesi gösterdiğini bulmuşlardır. Bundan dolayı PRP eklenmesinin ilave önemli bir etki göstermediğini iddia etmişlerdir.

Taschieri ve ark. ${ }^{38}$ minimal invaziv osteotomi ile sinüs lift uyguladıkları 25 hastaya sadece PRP uygulayarak 65 implant yerleştirmişlerdir. Bu yöntemlerin kalıc sonuçlar oluşturduğu ve atrofik posterior maksillası olan hastalarda güvenle kullanılabileceğini bildirmişlerdir.

Galindo-Moreno ve ark. ${ }^{39}$ sinüs duvarı augmentasyonunda kortikal kemik, bovin kemiği ve PRP karışımı kullanmışlar ve bu araştııııılar bu karışımın sinüs augmentasyonunda başarılı sonuçlar oluşturduğunu rapor etmişlerdir.

Nikolidakis ve ark. ${ }^{40}$ sinüs augmentasyonu sonrasında PRP ve $\beta$-TCP kombinasyonu ile yapılan greftin yeni kemik oluşumuna katkısını incelemişler, ancak ek bir katkı sağlamadığını gözlemlemişlerdir. Ancak bu yöntemin implant için yeterli stabilite sağlayacak kemik sağladığını da belirtmişlerdir. 
Mendonça-Caridad ve ark. ${ }^{41}$ kalvariyal kemik, PRP ve $\beta$-TCP kombinasyonunun etkinliğini sinüs augmentasyonu sonrasında tek aşamalı implant yerleştirdikleri 30 hastada uzun dönemde değerlendirmişlerdir. Bu çalışmanın sonuçlarının tatmin edici olduğu ve bu uygulama ile daha kısa sürede kemik iyileşmesi sağlandığı belirtilmiştir.

Yukarıdaki araştıııııların aksine, bazı araştııclar, greft materyaline PRP eklenmesinin veya PRP'nin tek başına kullanımının sinüs augmentasyonu sonrasında yeni kemik oluşumu ve oluşan yeni kemik kalitesine önemli bir etki sağlamadığını bildirmişlerdir. Schaaf ve ark. ${ }^{42}$ sinüs augmentasyonu yapılan ve implant yerleştirilen 34 hasta üzerinde yaptıkları çalışmada PRP ve otojen greft kombinasyonu ile sadece otojen kemik grefti uygulamasından 4 ay sonra yaptıkları tomografik değerlendirmede kemik dansitesinde gruplar arasında fark bulamamışıı. Aynı araştııııılar yaptıkları başka bir çalışmada ${ }^{43}$ sinüs augmentas- yonunda PRP'nin yüzeysel kullanımının kemik hacmi ve kemik rejenerasyonunu artırdığına dair bir bulguya rastlamamışlardır.

Carlson ve Robert ${ }^{44}$ yaptıkları literatür değerlendirmesinde şu yargıya varmışlardır: PRP oral ve maksillo-fasiyal cerrahi alanındaki uygulamalarda cerrahi sonuçların geliştirilmesi ve iyileştirilmesinde etkili bir yöntemdir. Ayrıca PRP, periodontal rejeneratif tedavide garantili sonuçlar oluşturmaktadır. Ancak, literatür derlemelrine göre PRP'nin sinüs augmentasyonundaki etkinliği tartışmalıdır. 2016 yılında Lemos ve ark. $^{45}$ tarafindan yapılan bir sistematik derleme ve meta analiz çalışması, maksiller sinus augmentasyonunda kullanılan greft materyaline PRP eklenmesinin kemik formasyonu ve implant devamllığı üzerine hiçbir olumlu etkisinin olmadığını göstermiştir.

Arora ve ark.NIN ${ }^{46}$ MEDLINE ve COCHRANE klinik deneyler merkezi verilerinin üzerinde yaptıkları sistematik literatür derleme, sinüs augmentasyonunda kullanılan greft materyaline PRP eklenmesiyle ilgili aşağıdaki sonuçları göstermiştir:

1. İnsanlar üzerinde yapılan klinik çalışmaların azlığına rağmen, bu çalışmalarda kemik greft materyallerine PRP eklenmesi erken kemik rejenerasyonu ile sert ve yumuşak dokuların iyileşme zamanlarının azalmasına yol açacak faydalar sağlayabilir. Ancak çalışmalarda belirtilen bu faydalar klinik ve istatistiksel önemden uzaktır.
2. Sinüs augmentasyonunda PRP kullanımını kuvvetli bir şekilde destekleyecek insanlar üzerinde yapılan hiçbir klinik çalışma bulunmamaktadır.

3. Bu konuda yapılmış klinik olarak kontrollü çalışmalar yetersizdir.

4. Bu çalışmalarda teorik olarak PRP kullanımının sert ve yumuşak doku iyileşmesine faydalı etkiler oluşturabileceği bildirilmesine rağmen, yapılan bu çalışmaların çalışma dizaynları ile cerrahi tekniklerinin farklı olması ve farklı başarı kriterleri kullanmaları PRP'nin klinik kullanımının faydalarının değerlendirilmesini zorlaştırmaktadır.

\section{KAYNAKLAR}

1. Soost F, Koch S, Stoll C, Amthauer H, GrosseSiestrup C, Zorn P. Validation of bone conversion in osteoconductive and osteoinductive bone substitutes. Cell Tissue Bank 2001;2:77-86.

2. Albrektsson $T$, Johansson C. Osteoinduction, osteoconduction and osseointegration. Eur Spine J 2001;Suppl 2:S96-101.

3. Keating JF, McQueen MM. Substitutes for autologous bone graft in orthopaedic trauma. J Bone Joint Surg Br Vol 2001:83:3-8.

4. Cornell CN, Lane JM. Current understanding of osteoconduction in bone regeneration. Clin Orthop and Related Res 1998;355 Suppl:S267-73.

5. Kahnberg K. Bone Grafting Techniques for Maxillary Implants. Hong Kong, Blackwell Munksgaard, 2005:1-7.

6. Fürst $G$, Gruber R, Tangl $S$, Zechner W, Haas R, Mailath G, Sanroman F, Watzek G. Sinus grafting with autogenous platelet-rich plasma and bovine hydroxyapatite. A histomorphometric study in minipigs. Clin Oral Implant Res 2003;14:500-8.

7. Stevenson S. Biology of bone grafts. Orthop Clin North Am 1999;30:543-52.

8. Marx RE. Platelet-Rich Plasma: A Source of Multiple Autologous Growth Factors for Bone Grafts. In: Lynch SE, Genco RJ, Marx RE (eds). Tissue Engineering: Applications in Maxillofacial Surgery and Periodontics. Chicago; Quintessence Publishing Company: 1999. p.71-82.

9. Marx RE, Carlson ER, Eichstaedt RM, Schimmele SR, Strauss JE, Georgeff KR. Platelet-rich plasma: Growth factor enhancement for bone grafts. Oral Surg Oral Med Oral Pathol Oral Radiol Endod 1998;85:638-46. 
10. Eppley BL, Woodell JE, Higgins JP. latelet quantification and growth factor analysis from platelet-rich plasma: implications for wound healing. Plast Reconstr Surg 2004;114:1502-8.

11. Weibrich G, Kleis WK, Hafner G, Hitzler WE. Growth factor levels in platelet-rich plasma and correlations with donor age, sex, and platelet count. J Craniomaxillofac Surg 2002;30:97-102.

12. Yazawa M, Ogata $H$, Nakajima $T$, Mori T, Watanabe N, Handa M. Basic studies on the clinical applications of platelet-rich plasma. Cell Transplant 2003;12:509-18.

13. Pietrzak WS, Eppley BL. Platelet rich plasma: biology and new technology. J Craniofac Surg 2005; 16:1043-1054.

14. Intini $G$. The use of platelet-rich plasma in bone reconstruction therapy. Biomaterials 2009;30:4956-66.

15. Nikolidakis D, Jansen JA. The biology of plateletrich plasma and its application in oral surgery: literature review. Tissue Eng Part B Rev 2008;14:249-58.

16. Eppley BL, Pietrzak WS, Blanton M. Platelet-rich plasma: a review of biology and applications in plastic surgery. Plast Reconstr Surg 2006;118: e147- 59.

17. Efeoglu C, Akçay YD, Ertürk S. A Modified Method for Preparing Platelet-Rich Plasma: An Experimental Study. J Oral Maxillofac Surg 2004;62:1403-7.

18. Della Valle A, Sammartino G, Marenzi G, Tia M, Espedito di Lauro A, Ferrari F, Lo Muzio L. Prevention of postoperative bleeding in anticoagulated patients undergoing oral surgery: use of platelet-rich plasma gel. J Oral Maxillofac Surg 2003;61:1275-8.

19. Dugrillon $A$, Eichler $H$, Kern $S$, Kluter $H$. Autologous concentrated platelet-rich plasma (cPRP) for local application in bone regeneration. Int J Oral Maxillofac Surg 2002;31:615-9.

20. Sánchez AR, Sheridan PJ, Kupp LI. Is Platelet-rich Plasma the Perfect Enhancement Factor? A Current Review. Int J Oral Maxillofac Implants 2003;18:93103.

21. Lucarelli E, Beccheroni A, Donati D, Sangiorgi L, A C. Plateletderived growth factors enhance proliferation of human stromal stem cells. Biomaterials. 2003;24:3095-100.
22. He L, Lin $Y$, Hu X, Zhang $Y$, Wu H. A comparative study of platelet-rich fibrin (PRF) and platelet-rich plasma (PRP) on the effect of proliferation and differentiation of rat osteoblasts in vitro. Oral Surg Oral Med Oral Pathol Oral Radiol Endod 2009;108:707-13.

23. Ott SM. New Aspects of Normal Bone Biology. In: Olgaard K, Salusky IS, Silver J (eds). The Spectrum of Mineral and Bone Disorders in Chronic Kidney Disease. $2^{\text {nd }}$ ed. Oxford; Oxford University Pres: 2010. p.15-29.

24. Dohan Ehrenfest DM, Rasmusson L, Albrektsson T. Classification of platelet concentrates: from pure platelet-rich plasma (P-PRP) to leucocyte- and platelet-rich fibrin (L-PRF). Trends Biotechnol 2009;27:158-67.

25. Anitua $E$. The use of plasma-rich growth factors (PRGF) in oral surgery. Pract Proced Aesthet Dent 2001;13:487-493.

26. Boyne PJ, James RA. Grafting of the maxillary sinus floor with autogenous marrow and bone. J Oral Surg 1980;38:613-6.

27. Tatum H. Maxillary and sinus implant reconstruction. Dent Clin North Am 1986;30:20729.

28. Summers RB. A new concept in maxillary implant surgery: the osteotome technique. Compend Contin Educ Dent 1994;15:152-6.

29. Pozzi A, Moy PK. Minimally Invasive Transcrestal Guided Sinus Lift (TGSL): A Clinical Prospective Proof-of-Concept Cohort Study up to 52 Months. Clin Implant Dent Relat Res 2014;16:582-93.

30. Kfir E, Goldestein M, Abramovitz I, Mazor Z, Kfir V, Kaluski $E$. The effects of sinus membrane pathology on bone augmentation and procedural outcome using minimal invasive antral membrane balloon elevation. J Oral Implantol 2014;40:28593.

31. Kim DY, Itoh Y, Kang TH. Evaluation of the effectiveness of a water lift system in the sinus membrane-lifting operation as a sinus surgical instrument. Clin Implant Dent Relat Res 2012;14:585-94.

32. Ucer TC. Use of negative air pressure by nasal suction during maxillary sinus floor lift: audit of 13 consecutive sinus grafts. $\mathrm{Br} \mathrm{J}$ Oral Maxillofac Surg 2009;47:151-2. 
33. Mazor Z, Peleg M, Garg AK, Luboshitz J. Plateletrich plasma for bone graft enhancement in sinus floor augmentation with simultaneous implant placement: patient series study. Implant Dent 2004;13:65-72.

34. Anitua E, Prado R, Orive G. Bilateral sinus elevation evaluating plasma rich in growth factors technology: a report of five cases. Clin Implant Dent Relat Res 2012;14:51-60.

35. Riaz R, Ravindran C, Ramkumar, Nandakumar E. Efficacy of platelet rich plasma in sinus lift augmentation. J Maxillofac Oral Surg 2010;9:22530.

36. Thor A, Franke-Stenport V, Johansson CB, Rasmusson L. Early bone formation in human bone grafts treated with platelet-rich plasma: preliminary histomorphometric results. Int J Oral Maxillofac Surg 2007;36:1164-71.

37. Schlegel KA, Zimmermann $R$, Thorwarth $M$, Neukam FW, Klongnoi B, Nkenke E, Felszeghy E. Sinus floor elevation using autogenous bone or bone substitute combined with platelet-rich plasma. Oral Surg Oral Med Oral Pathol Oral Radiol Endod 2007;104:e15-e25.

38. Taschieri S, Corbella S, Del Fabbro M. MiniInvasive Osteotome Sinus Floor Elevation in Partially Edentulous Atrophic Maxilla Using Reduced Length Dental Implants: Interim Results of a Prospective Study. Clin Implant Dent Relat Res 2014;16:185-93.

39. Galindo-Moreno P, Avila G, Fernández-Barbero JE, Aguilar M, Sánchez-Fernández E, Cutando A, Wang $\mathrm{HL}$. Evaluation of sinus floor elevation using a composite bone graft mixture. Clin Implant Dent Relat Res 2007;18:376-82.

40. Nikolidakis D, Meijer GJ, Jansen JA. Sinus floor elevation using platelet-rich plasma and betatricalcium phosphate: case report and histological evaluation. Dent Today 2008;27:66-70.

41. Mendonça-Caridad JJ, Nunez M, Juiz-Lopez P, PitaFernandez S, Seoane J. Sinus floor elevation using a composite graft: clinical outcome of immediate implant placement. Int J Oral Maxillofac Implants 2013;28:252-60.

42. Schaaf H, Streckbein $P$, Lendeckel $S$, Heidinger KS, Rehmann P, Boedeker RH, Howaldt HP. Sinus lift augmentation using autogenous bone grafts and platelet-rich plasma: radiographic results. Oral
Surg Oral Med Oral Pathol Oral Radiol Endod 2008;106:673-8.

43. Schaaf $H$, Streckbein $P$, Lendeckel $S$, Heidinger $K$, Görtz B, Bein G, Boedeker RH, Schlegel KA, Howaldt HP. Topical use of platelet-rich plasma to influence bone volume in maxillary augmentation: a prospective randomized trial. Vox Sang 2008;94:64-9.

44. Carlson N, Robert B. Platelet-rich plasma: Clinical applications in dentistry. J Am Dent Assoc 2002;133:1383-6.

45. Lemos CA, Mello CC, Dos Santos DM, Verri FR, Goiato MC, Pellizzer EP. Effects of platelet-rich plasma in association with bone grafts in maxillary sinus augmentation: a systematic review and meta-analysis. Int J Oral Maxillofac Surg 2016;45:517-25.

46. Arora NS, Ramanayake T, Ren YF, Romanos GE. Platelet-rich plasma in sinus augmentation procedures: a systematic literature review: Part II. Implant Dent 2010;19:145-57.

\section{Yazışma Adresi}

Dr. Songul CÖMERT KILIÇ, DDS, PhD. Erzurum Ağız ve Diş Sağlığı Merkezi, Ağız Diş ve Çene Cerrahisi Kliniği, Yakutiye/ ERZURUM

Tlf: +90.442 .2334590$

Fax: +90.442 .2360945$

e-mail: drsckilic@yahoo.com.tr 